\title{
Top Five Ranking of Sharia Financial Acades with the Potential of Fraud (Case Study of Three Sharia Commercial Banks) In North Sumatera
}

\author{
M. Yasir Nasution ${ }^{1}$, Andri Soemitra ${ }^{2}$, Wilchan Robain ${ }^{3}$ \\ 1,2,3 Universitas Islam Negeri Sumatera Utara, Indonesia \\ andrisoemitra@gmail.com,wilchanrobain@gmail.com
}

\section{Abstract}

The purpose of this study was to find the top five rankings of sharia finance contracts with the potential for fraud (case study of three sharia commercial banks) in North Sumatra. This research uses a combination of quantitative and qualitative research methods, data analysis with Analytical Networking Process (ANP) techniques through Super Decision Software, conducting open and in-depth interviews with 9 respondents, Focus Group Discussion (FGD) with practitioners and sharia finance experts. In this case, it was found that the top five rankings of sharia financial contracts have the potential for fraud (a case study of three sharia commercial banks) in North Sumatra, namely Ijarah 23.34\%, murabahah $14.86 \%$, kafalah or kafalah bil ujrah $8.71 \%$, musyarakah $8.22 \%$ and mudharabah $6.28 \%$.

\author{
Keywords \\ sharia financial agreements, \\ potential; fraud

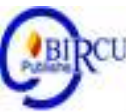

\section{Introduction}

Fraudulent practices or fraud in the language of accounting are very often heard about in people's lives. Even though it has been coated with various kinds of prevention methods such as legal sanctions, social sanctions and so on, it does not make a person deterrent and give up. This condition is not only carried out by the poor, but also by those who live in their daily life with wealth and luxury. It is as if they feel dissatisfied with the good conditions in their life but feel they are still lacking so they continue to look for bad opportunities in every activity.

If there is an inappropriate act in finance then the word fraud always appears which in simple language is fraud, generally people think that an act of disgrace or a violation is an act of fraud, according to scientific experts, an act of disgrace or violation is not necessarily a fraud. As a parable, if the cashier clerk underpayment or the loss of money in a bank has a different condition, can it be said that a fraud was committed by a cashier? Of course not certain. Fraud actions must be fulfilled by all elements of deliberate action, and the question that needs to be verified is that the loss of money was caused by deliberate factors or taken or just negligence. Then from the results of the examination carried out, the loss of money was due to the cashier's excess in returning the money to the customer, so this condition is considered as negligence or neglation, even though it must require continuous proof, for example: does the cashier officer cooperate with the customer or not? In the sense of proving that an act of disgrace can be said to be an act of fraud, it must fulfill the elements of "deliberate action".

Action fraudit is strictly prohibited to do so in all aspects of existing norms, be it religious, social, cultural, social and state norms. In the Koran, it is very clear that the prohibition of fraud is in Surah Al Muthafifin / 83: 1 which reads: 
One of the scholars of interpretation of the Syafi'I Al Hafidz Ibn Katsir rahimullah school of thought in his interpretation of the Tafsir Al Quranul 'Adzhim, he explained asbabun nuzul (because of the decline) of this verse was when the Prophet SAW migrated from the city of Mecca to Medina he found the people of Medina to be very bad at measuring and weigh. If they are the ones buying the item, they want the measure to be perfect, but when they sell the item, they reduce the measure. This kind of practice was often carried out by the inhabitants of the city of Medina before the Prophet came to the city of Medina. So that Al Muthafifin's letter came down as a warning to them.

Based on the report data The Association of Certified Fraud Examiners (ACFE) states that the percentage of the fraud model that most often occurs is asset misappropriation or misuse of assets, which can reach 57\%, the largest compared to other fraud models, namely corruption or corruption and financial statement fraud or fraudulent financial statements. This can be seen from the image below:

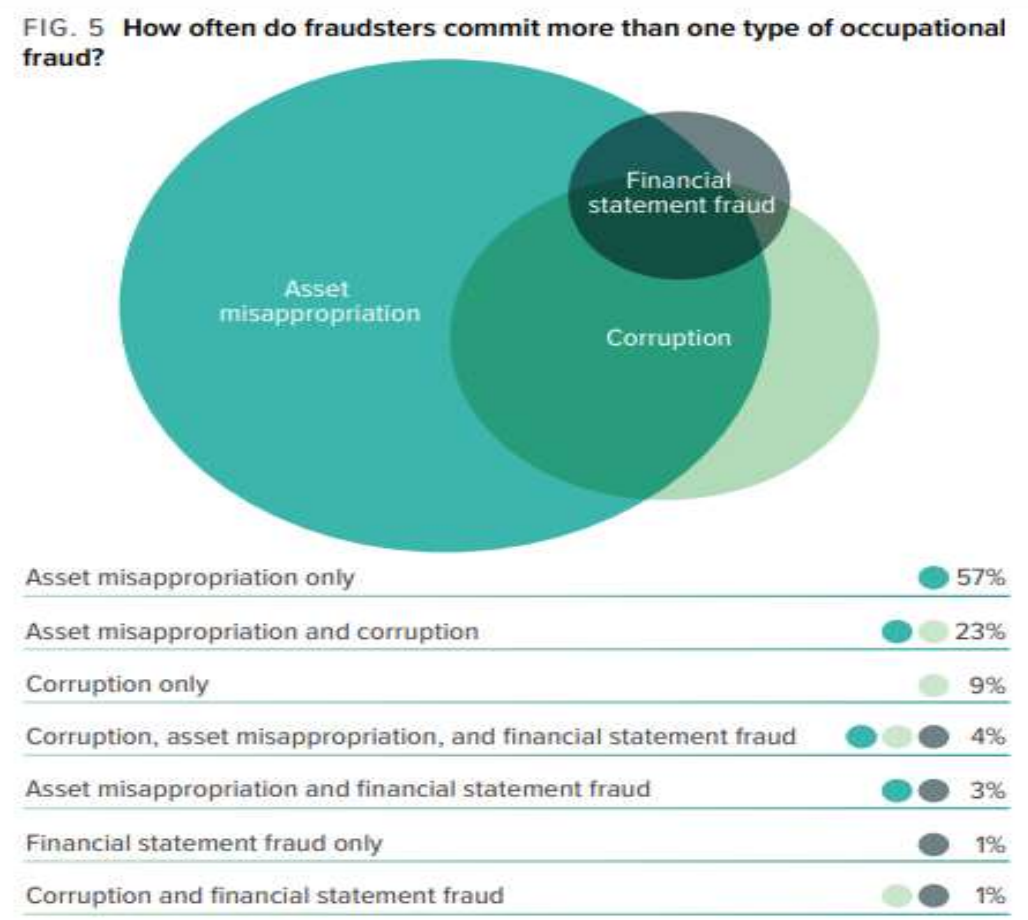

Figure 1. Percentage of Fraud Model

Source: 2018 ACFE Report to the Nations

All the existing Islamic financial contract instruments, of course everything is good to be applied as long as it is in accordance with the actual designation needs, but surely all Islamic financial contract instruments have the potential to be the easiest to apply to customers. Therefore, there will be potential for fraud if the Islamic financial contract instruments are implemented, then this will have implications for the financing process which is feared that there will be stagnation or intermittent payment of installments, because from the beginning the process has been made easy according to demand and needs of customers or proposers for financing. 
The financial report is the final result of the accounting cycle in the form of company financial information that describes the condition of the company which is used as a form of management responsibility for its performance so far. (Prayogo and Afrizal, 2021)

Fraud which is carried out in Islamic banking occurs because of many kinds of factors from the inside and outside the Islamic banking itself. If viewed from the inside, what might trigger accidental fraud lies in the competence of its human resources or human resources. Do these human resources understand sharia and banking well or not. From the outside, it is possible that the environmental side such as the family may have urgent needs so that they are forced to commit fraud.

Events that result in fraud in Islamic banking can also be felt by parties inside and outside of Islamic banking. From the inside, for example, banking operations are disrupted if the continuity of fraud that occurs is very high. From the outside, fraud can cause a decrease in customer confidence in the management of funds carried out by Islamic banking because customers will feel disadvantaged in terms of finances or financially.

The formation of fraud is a crime that is very dangerous for yourself and the environment. Forms of fraud must be resolved immediately by reducing all forms of financial or nonfinancial losses arising from such actions. The formation of fraud also adds to readers' knowledge of various possible frauds, factors and strategies that need to be done.

Based on the background of the problem that the researcher has described above, the researcher wants to observe further and deepen and disclose this phenomenon in an article entitled "The Top Five Rank Islamic Financial Agreements Potential for Fraud (Case Study of Three Islamic Commercial Banks) in North Sumatra.)". Hopefully researchers can contribute well in this research.

\section{Review of Literatures}

\subsection{Definition of Sharia Financial Agreements}

Sharia banking is one of the financial institutions that has the function of balancing, coordinating and coordinating various sectors of the economy. The strategic role in the development is to improve the quality of livelihoods of citizens as a whole through national stability and economic growth. Meanwhile, the bank is "Department of store, which is a body or organization that provides services / services for various financial services where the vital activities are receiving payments, savings, current deposits and deposits, which is used to be able to make credit / money loans aimed at every community needs, and banks are places used in exchanging money. (Ichsan et al, 2021)

The term agreement in Indonesian law is called a contract in Islamic law. Literally, the

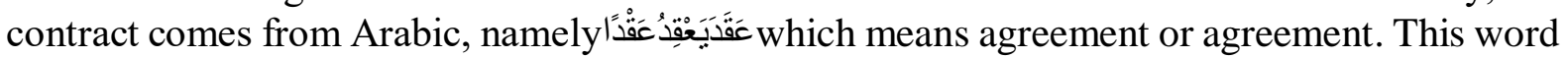
can also be interpreted as a rope that binds because there will be a bond between people who have contracted. Wahbah az-Zuhaili defines the contract as: "The bond between two things, either tangible or meaningful, from one aspect or two.

According to the Sharia Economic Law Compilation, what is meant by a contract is an agreement in an agreement between two or more parties to perform and or not to carry out certain laws. According to Basya in Murshid al-Hairan, the contract is a meeting of consent proposed by one party with the Kabul from another party which has legal consequences on the object of the contract.

From some of these definitions in above can be shown that:

First, a contract is having a relationship or a meeting of consent and consent which results in legal consequences. Ijab is an offer submitted by one of the parties, and kabul is the answer to the agreement given by the contract partner in response to the first party's offer. A contract 
does not occur if the statement of the will of each party is not related to one another because the contract is a relationship between the will of the two parties which is reflected in the consent of the Kabul.

Second, a contract is a legal action between two parties because a contract is a meeting of consent which represents the will of one party and a kabul which states the will of the other party. One party's legal actions, such as promises to give gifts, wills, endowments, or waivers of rights, is not a contract. Because these actions are not two-sided actions and therefore do not require consent. The conception of the contract as an act of two parties is the view of modern Islamic jurists. In pre-modern times there were differences of opinion. Most of the jurists did clearly separate the unilateral will from the covenant, but others made the covenant include unilateral will.

Third, the purpose of the contract is to give birth to something legal consequences. More explicitly, the purpose of the contract is a common goal that is aimed at and which the parties intend to realize through making the contract.

As the definition of the contract above is an agreement, the terms related to the agreement in the Koran have at least two terms, namely al-aqdu (akad) and al-ahdu (promise). The term al-aqdu is found in the letter Al-Maidah verse 1, that in the letter there is the word bil uqud which is formed from the word al-uqud or the plural form of interpretation of the word al-aqdu. The Ministry of Religion of the Republic of Indonesia means agreement (contract).

Meanwhile, the word al-ahdu is found in surah Ali Imron verse 76, that in this verse there is the word bi-ahdihi which is formed from the letters, the word al-ahdi and 'hi', namely 'dhomir' or pronouns. The translation team of the Ministry of Religious Affairs interpreted this as a promise.

According to Abdoerrauf, al-aqdu (engagement) can occur in three stages, namely:

a. The first stage: Al-ahdu (agreement), which is a statement from someone to do something or not to do something and it has nothing to do with the wishes of others.

b. Second stage: The second party agrees to do or not do something as a reaction to the promise stated by the first party. The statement must be in accordance with the promise of the first party.

c. The third stage: Al-aqdu (contract / engagement), namely the implementation of the two promises.

Different agreements with treatyalthough both are almost the same which is a form of engagement. A contract is a mutual agreement between the two parties, either verbally, gesture, or in writing which has binding legal implications for carrying it out. Whereas waad is a promise between one party to another, the party who is given a promise does not assume any obligation to the other party. In waad the form and condition have not been determined in detail and specifically. If the party who promised cannot carry out his promise, then the sanction he received is more of a moral sanction.

From the description in above, it can be stated that the position and function of the contract is the most important tool in whether or not muamalah is the final goal.

The contract is divided into various classifications from several points of view. However, the classification of the contract is divided into, namely a named contract and an anonymous contract.

a. Named contract

What is meant by a named contract is a contract whose name has been determined by the legal maker and the specific provisions that apply to it and do not apply to other contracts.

Al-Kasani (587/1190) stated that the named contract includes: Leasing (al-ijarah), Placement (al-istishna), Buying and selling (al-bai '), Guarantees (al-kafalah), Transfer of debts (al- hawalah), Granting power (al-wakalah), Peace (ash-shulh), partnership (ash-syirkah), 
profit sharing (al-mudharabah), grants (al-hibah), pawn (ar-rahn), land cultivation ( almuzara'ah), plant maintenance (al-musaqah), custody (al-wadiah), borrow-to-use (al-ariyah), distribution (al-qismah), wills (al-washaya), stomach (al- qardh).

b. Anonymous contract

An anonymous contract is a contract that is not specifically regulated in the fiqh books under one specific name. In other words, an anonymous contract is a contract that is not specified by the lawmaker with a specific name and there is no separate regulation regarding it. Not all existing contracts are used in the financing process in Islamic banking. The researcher only limits it to fourteen contracts, which are as follows:

a. Murabaha; Reciprocal selling with profit agreement. Sales agreement in which the seller states the costs and benefits.

b. Regards; Salam means an agreement with a prepayment made for goods to be shipped later.

c. Istishna; Agreement to manufacture goods and commodities, with cash advance payment and delivery of goods later.

d. Mudaraba; Under a mudaraba agreement, the bank provides the capital needed for a project in which the entrepreneur manages the project.

e. Musharaka; Financing through equal involvement is called musyarakah. Two or more partners put their capital and expertise into the business.

f. Musytarakah mudaraba; Musytarakah mudaraba is a combination of two words, namely mudaraba and musytarakah. Mudharabah is an investment agreement for the manager to conduct a certain business by dividing the proceeds based on a ratio agreed by both parties, while the capital loss will be borne by the owner of the capital.

g. Musyarakah mutanaqisah; is an agreement between two parties who unite against an item in which one party purchases the other's share in stages.

h. Ijarah; Refers to the agreement between the tenant and the lessee.

Ijarah It can also be referred to as al-Kira ', namely rent or wages by selling benefits, namely use at a specified price or fee.

i. Ijarah Munjukiyah Bittamlik; is a contract of provision of funds in the context of transferring use rights or benefits of goods and services based on a lease transaction with an option to transfer ownership of the goods.

j. Hawalah; is the transfer of debt from liability owed to the responsibility of others. Initially, hawalah applies in matters of accounts payable where the debtor transfers the responsibility to pay his debt to someone else to be paid to the owner of the debt.

k. Wow; is to appoint someone to take the place of the person who appointed him to carry out a task for his party. Wakalah is an agreement that empowers the person representing the representative to carry out a task or work for the person representing that person.

1. Kafalah; Kafalah and Dhmanah have the same meaning, namely assurance.

m. Ju'alah; Ibn Qudamah Al-Hanbali said that ju'alah is like saying "Whoever finds something and then returns it to me or my livestock is lost or makes this wall then I will give him such a reward.

n. Qardh; Interest-free loan. The borrower is only required to return the loan principal. Qardh which is also called al-dayn and al-salf means debt. Qardh al-Hasan is debt without conditions or promises to pay back more than the debt, but giving souvenirs to those who have a debt when paying it is not because of terms or promises. 


\subsection{Definition of Potential}

There are many experts who explain the meaning of the word potency, one of the experts who try to explain it is:

a. Wiyono; According to him, potential means the basic ability of someone who is still hidden and waiting to be raised into a real strength. According to Wiyono's opinion, potential can be said to be an ability that is still hidden and ready to be realized and can be utilized in human life itself.

b. Majdi; potential is an ability that can still be developed better, in simple terms potential is a hidden ability that still needs to be developed.

c. Endra K Pihadhi; explained that potential is an energy or strength that is still not used optimally. So that potential is interpreted as a hidden strength which can be in the form of strength, interest, talent, intelligence, etc. which are still not used optimally, so that the benefits are still not felt.

d. Sri Habsari; also tries to explain the meaning of the word potential, which according to him potential is the ability and strength of oneself that can be improved and developed for the better with proper and good facilities and infrastructure.

The view of the Koran is that there is a form that does not appear, no matter how sharp the eyes of the head or mind are, with many things beyond the reach of the human senses and intellect. Only the heart can grasp it through revelation, inspiration and intuition.

It is also stated in the Koran that every human being has the potential to be developed in order to be good and is a necessity for humans to achieve life in the world and in the hereafter as stated in the Koran in surah An Nahl / 16: 78 which reads:

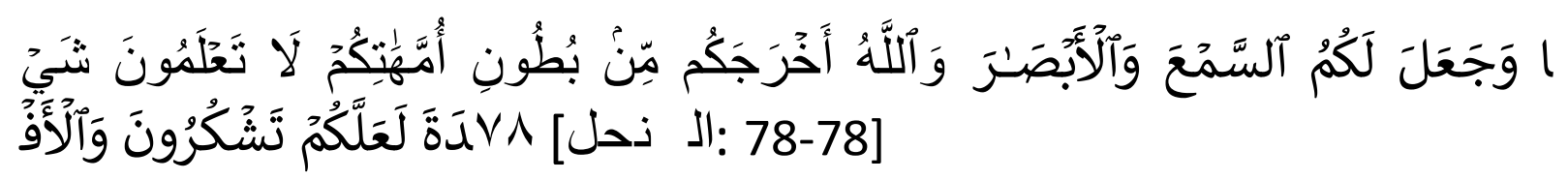

Then Allah took you out of your mother's stomach knowing nothing, and He gave you hearing, sight and heart, so that you would be grateful.

Human potential is a mystery. Therefore, the recognition and measurement of human potential is to uncover the mysteries that exist within oneself. By recognizing and measuring human potential, among others, will provide a picture of a person's personality, a picture of a person's tendency to behave. This trend is not fixed price, but is subject to change. "Trend" is not "certainty". The development of human potential must have a measure to determine the extent of an individual's potential, either through obtaining self-introspection or through obtaining feedback from others and conducting psychological tests.

\subsection{Definition Fraud}

Through Bank Indonesia Circular Number 13/28 / DPNP dated December 9, 2011, which explains the Implementation of Anti-Fraud Strategies for Commercial Banks states: that what is meant by fraud in this provision is that activities are carried out intentionally to deceive, to deceive or to manipulate banks. , manipulating customers or other parties within the Bank so that the bank or customers or other parties suffer losses and the perpetrators of fraud gain either directly or indirectly.

Understanding this definition, simply an act of fraud, especially that which occurs at a bank, can be said to be fraud if it meets four elements, namely:

a. Deviating or allowing standards or procedures or the company's internal code of ethics to be violated by disregarding criminal law and banking laws.

b. Deliberate actions or omissions or violations. 
c. Loss directly or indirectly.

d. Benefit the actors, either directly or indirectly.

Based on statistical data on fraud fraud according to the Association of Certified Fraud Examiners in 1994, business or company losses due to fraud include:

a. Sales losses range from 0.5 percent to 2 percent due to fraud and dishonesty of employees.

b. One third of business failures or business failures are due to internal fraud.

c. Only 30 percent of business losses in retail originate from store theft or Shop Lifter, while 70 percent are stolen by employees themselves.

Actions in the form of fraud occur due to the fulfillment of four compositions of fraud, namely:

1) There is a plan or intention or Plan.

2) There is the ability of the perpetrator to commit fraud or Capability.

3) There is an opportunity or Chance.

4) There are tools that help the perpetrator commit fraud or tools.

The composition described above is the most likely to be minimized is the composition of opportunity or Chance. Good internal control is one way to prevent fraud.

It is also illustrated that the factors behind fraud are not only due to the intention of the perpetrator but also the motive of the perpetrator can be caused by several other factors, including:

a. Have a desire for personal gain, company advantage or group advantage.

b. Have weak controls that allow you to overly trust staff or coworkers, by oversimplifying processes or not caring about violations of internal company procedures.

c. Feeling dissatisfied with an individual or business.

d. Has an urgent need from the perpetrator.

e. Having excessive lifestyle and pride.

Separately, the perpetrators' motives for committing fraud were discussed in the form of the fraud triangle, namely:

a. Perceived Opportunitor there is an opportunity due to negligence or weak internal control and it may cause the perpetrator or employee to have no intention of committing fraud.

b. Pressureor pressure; Pressure can arise due to individual factors such as lifestyle, urgent needs due to family illness or due to pressure from companies such as achieving targets, etc.

c. Rationalizationor An act of justification; Usually this occurs together with the reason that activities carried out for the benefit of the company are carried out through the habits of other employees, especially superiors or seniors, so that the perpetrator takes parables from these habits because he thinks something is normal.

Something that causes or may arise irregularities or fraud is based on the opinion of Zainul Bahar Noor which stimulates and leads to corruption as follows:

a. Always Window Dressing in publishing the balance sheet and profit and loss at the end of the year.

b. Inflation of the number-level figures through multiplying the income figures, profits by crediting the income items from the debit of the income to be received. This method is used in an effort to convince the public that the bank is profitable, to attract more people.

c. Misunderstanding in the use of an acrual basic so that it can manipulate a bank that should be losing money into a lucky bank. The accrual basis method in determining the recognition of income on earning assets that results in differences in the amount of income stated in the financial reporting in the income statement and the income stated in the recorded profit sharing statement with real income in cash as received by the bank. Meanwhile, the income listed in the income statement includes both income that has been received in cash by the bank and income arising from the accrual process. 


\section{Research Methods}

This research was conducted with descriptive qualitative method and also through a quantitative approach. The descriptive qualitative method is used to build a concrete analysis in order to find the top five rankings of Islamic finance contracts with the potential for fraud in three Islamic commercial banks in North Sumatra which will also be enriched through literature studies in order to obtain information from primary sources (Michael, 2006) .

Whereas quantitative research is the values of change which can be expressed in numbers (scoring). The quantitative approach aims to provide a numerical description of the decomposition cluster on The top five rankings of Islamic financial contracts have the potential for fraudusing the Analytic Network Process (ANP) method with Super Decision software. The variables used in this study include aspects that are inThe top five rankings of Islamic financial contracts have the potential for fraud as illustrated in the conceptual framework below:

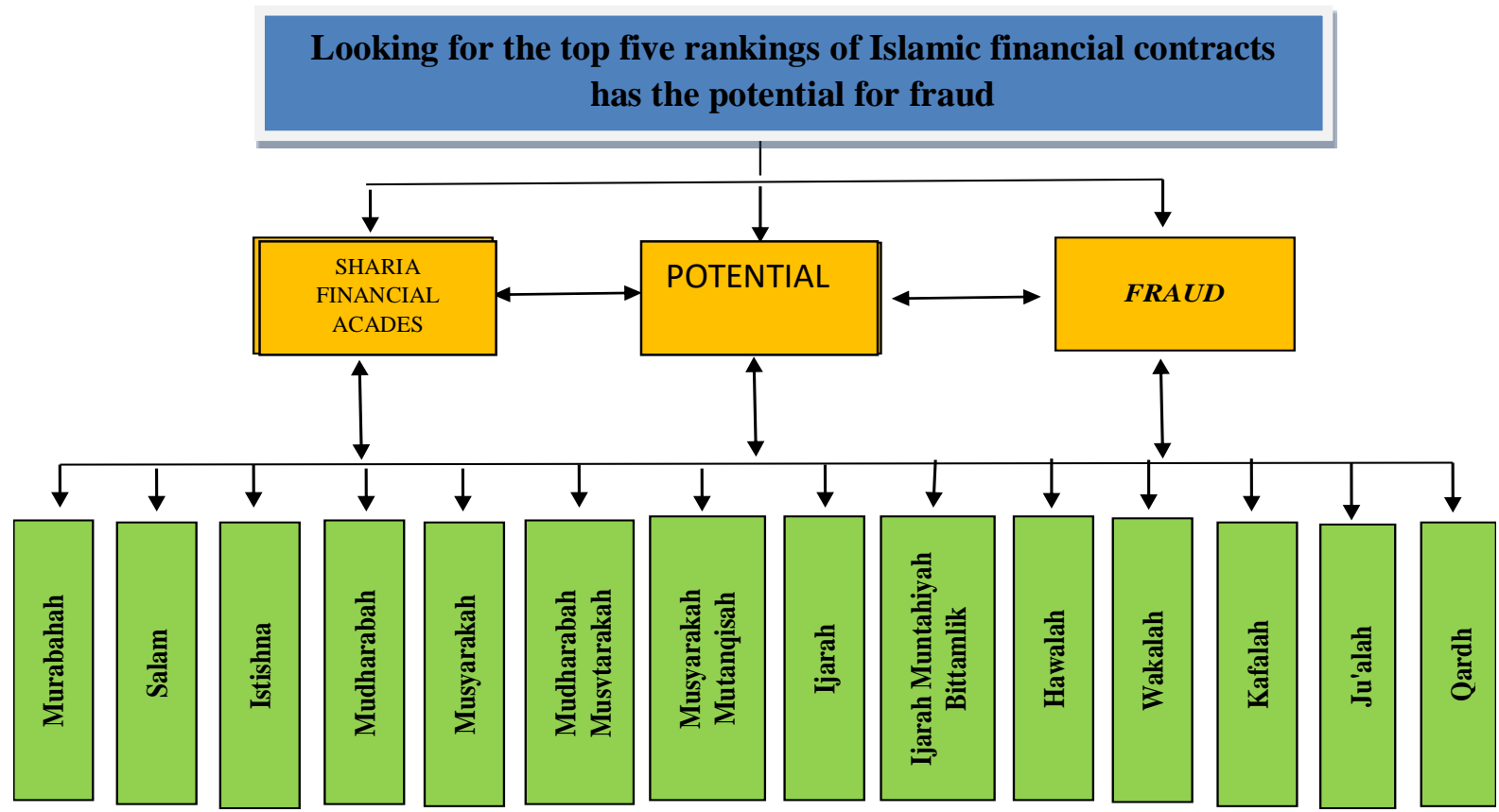

Figure 2. Conceptual framework

\section{Result and Discussion}

\subsection{Profile of Three Islamic Commercial Banks in North Sumatra}

a. Bank Aceh Syariah Branch S. Parman

It is a branch of Bank Aceh Syariah in Medan City, which is located on Jalan S. Parman No. 3-3A, Petisah Hulu Village, Medan Baru District, Medan City, which is one of the research sites conducted by researchers.

\section{b. BRI Syariah Lubuk Pakam Branch}

It is a branch of BRI Syariah in Lubuk Pakam City, which is located on Jalan Jenderal Sudirman No. 23 E, Lubuk Pakam, Deli Serdang Regencywhich is one of the research sites conducted by researchers. 


\section{c. Bank Muamalat Branch of Arief Rahman Hakim}

Is one of the branches of Bank Muamalat in Medan City is located at Jalan Arief Rahman Hakim No.70 AB, Sukaramai I Village, Medan Area District, Medan City, which is one of the research sites conducted by researchers

\section{d. Synthesis Analysis of the Top Five Rank Islamic Financial Agreements}

This discussion will describe the synthesis analysis of the problem of Islamic financial contracts in search The top five rankings of Islamic financial contracts have the potential for fraud according to Islamic finance practitioners. Based on the results of data processing, it is found that the priority of Islamic financial contracts is in the opinion of all respondents as shown in Figure 3.

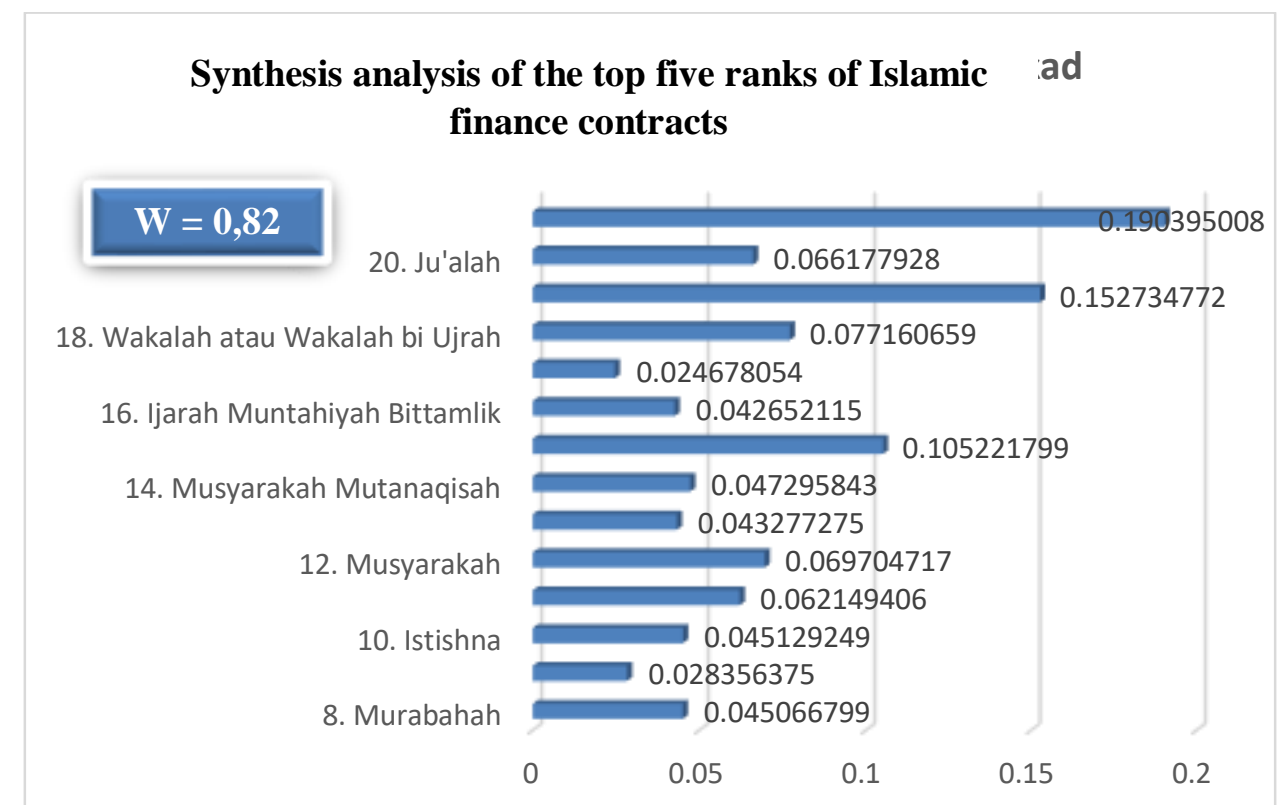

Figure 3. Synthesis of the Top Five Rank Islamic Financial Agreements Based on Average Value

Source: From interviews and data processing

Figure 3. shows that based on the combined opinion, the sharia financial contracts in the search for the top five levels of Islamic financial contracts according to Islamic finance practitioners are the first rank of the qardh contract of 0.190395008 or $19.04 \%$, the second rank of the kafalah or kafalah bil ujrah contracts 0.152734772 or $15.27 \%$, the third rank of ijarah contracts is 0.105221799 or $10.52 \%$, the fourth rank of wakalah or wakalah bil ujrah contracts is 0.077160659 or $7.72 \%$ and the fifth rank musyarakah is 0,069704717 or $6.97 \%$ and followed by rank six to fourteenth are ju'alah, mudharabah, musyarakah mutanaqisah, istishna, murabahah, mudharabah musytarakah, ijarah mintahiyah bittamlik, salam and hawalah contracts.

The results of the synthesis per respondent show that of the six respondents, none answered the problem of sharia financial contracts with uniform answers or were arranged based on the top five rankings according to Islamic finance practitioners are qardh, kafalah or kafalah bil ujrah, ijarah, wakalah or wakalah bil ujrah and musharkah according to Islamic finance practitioners. This is of course in line with the rater agreement value, which is $82 \%$ of the respondent's level of agreement with the answer sequence in the cluster of Islamic finance contracts according to Islamic finance practitioners. 
This discussion will describe the synthesis analysis of the problem of Islamic financial contracts in search The top five rankings of Islamic financial contracts have the potential for fraudaccording to Islamic finance experts. HAs a result of data processing, the priority is obtained from the issue of Islamic financial contracts according to the opinion of all respondents as shown in Figure 4.

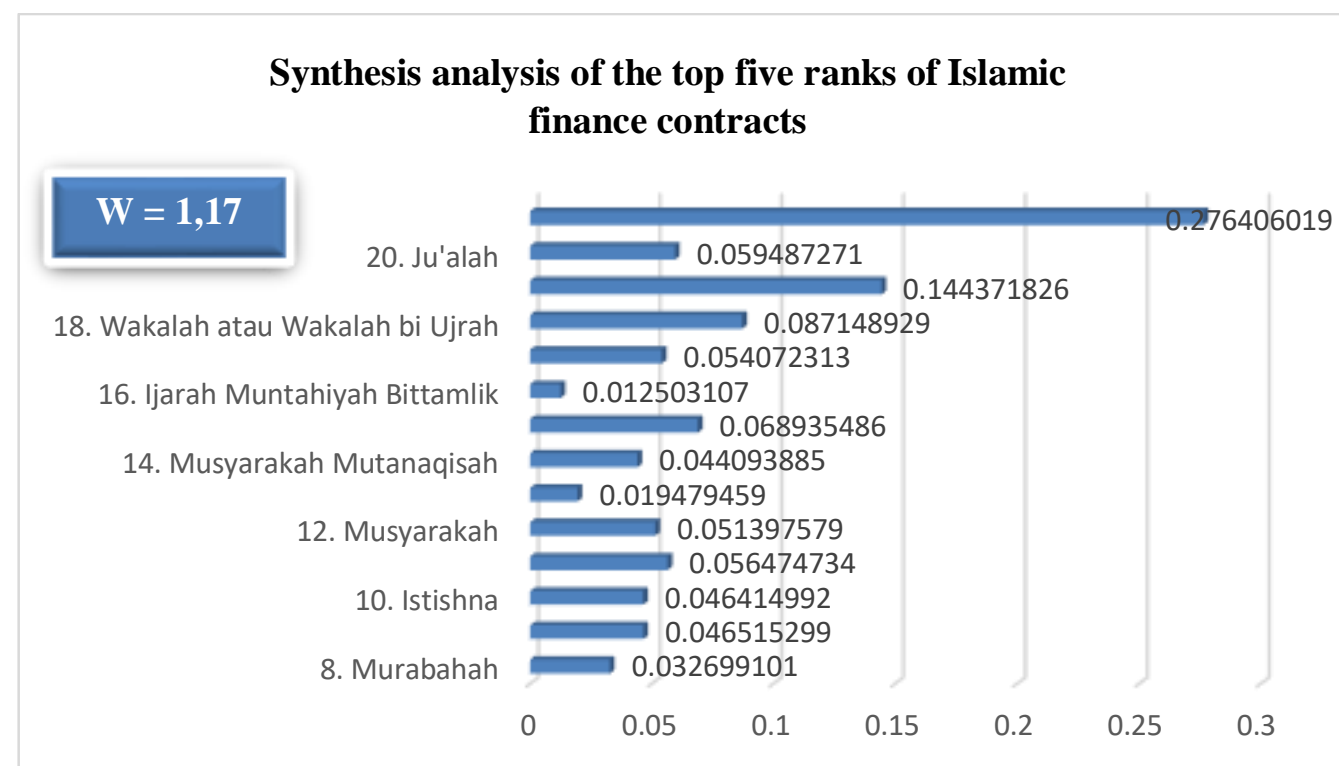

Figure 4. Synthesis of the Top Five Rank Islamic Financial Agreements Based on Average Value

Source: From interviews and data processing

Figure 4. shows that based on the combined opinion, the problem of sharia financial contracts in finding the top five levels of Islamic financial contracts according to Islamic finance experts is the first rank of the qardh contract of 0.276406019 or $27.64 \%$, the second rank of kafalah or kafalah contracts ujrah was 0.144371826 or $14.44 \%$, the third rank wakalah or wakalah bil ujrah was 0.087148929 or $8.71 \%$, the fourth rank ijarah contract was 0.068935486 or $6.89 \%$, and the fifth rank was ju 'alah amounting to 0.059487271 or $5.95 \%$ and followed by rank six to fourteenth are mudharabah, hawalah, musyarakah, salam, ishtisna, musyarakah mutanaqisah, murabahah, mudharabah musytarakah and ijarah mintahiyah bittamlik contracts.

The value of the synthesis per respondent shows that of the three respondents, none of them answered the problem of Islamic financial contracts with uniform answers or were arranged based on the top five rankings, namely qardh, kafalah or kafalah bil ujrah, wakalah or wakalah bil ujrah, ijarah, and ju ' no. This is of course in line with the rater agreement value, namely $117 \%$ of the respondent's level of agreement with the order of answers in the cluster of Islamic finance contracts according to Islamic finance experts. 
Table 1. Conclusion for Ranking Sharia Financial Agreements

\begin{tabular}{|c|c|c|c|c|c|c|c|c|c|c|c|}
\hline \multirow[t]{2}{*}{ Sharia financial acade sharia financial acades } & \multicolumn{3}{|c|}{$\begin{array}{l}\text { INTERVIEW } \\
\text { EXPERT }\end{array}$} & \multirow[t]{2}{*}{ Total } & \multirow[t]{2}{*}{$\begin{array}{l}\text { Total } \\
\text { ranking }\end{array}$} & \multirow{2}{*}{$\begin{array}{c}\text { Result } \\
\text { Practis } \\
\text { data }\end{array}$} & \multirow{2}{*}{$\begin{array}{c}\text { Result } \\
\text { Expert } \\
\text { data }\end{array}$} & \multirow[t]{2}{*}{ Total } & \multirow[t]{2}{*}{$\begin{array}{c}\text { Total } \\
\text { Rangking }\end{array}$} & \multirow[t]{2}{*}{$\begin{array}{c}\text { Total } \\
\text { |Rangking }\end{array}$} & \multirow[t]{2}{*}{ Conclussion } \\
\hline & $\begin{array}{clll}1 & & & \\
\end{array}$ & 2 & 3 & & & & & & & & \\
\hline Murabahah & 1 & 1 & 1 & 3 & 1 & 10 & 12 & 22 & 11 & 25 & 2 \\
\hline Salam & 10 & 5 & 10 & 25 & 8 & 13 & 9 & 22 & 12 & 47 & 12 \\
\hline Istishna & 11 & 2 & 6 & 19 & 5 & 9 & 10 & 19 & 8 & 38 & 8 \\
\hline Mudharabah & 8 & 10 & 3 & 21 & 6 & 7 & 6 & 13 & 6 & 34 & 5 \\
\hline Musyarakah & 12 & 4 & 2 & 18 & 4 & 5 & 8 & 13 & 7 & 31 & 4 \\
\hline Mudharabah Musytarakah & 9 & 9 & 8 & 26 & 10 & 11 & 13 & 24 & 13 & 50 & 13 \\
\hline Musyarakah Mutanaqisah & 13 & 3 & 9 & 25 & 9 & 8 & 11 & 19 & 9 & 44 & 11 \\
\hline Ijarah & 2 & 6 & 4 & 12 & 2 & 3 & 4 & 7 & 3 & 19 & 1 \\
\hline \begin{tabular}{|l} 
Ijarah Muntahiyah Bittamlik \\
\end{tabular} & 3 & 7 & 5 & 15 & 3 & 12 & 14 & 26 & 14 & 41 & 10 \\
\hline Hawalah & 14 & 13 & 11 & 38 & 14 & 14 & 7 & 21 & 10 & 59 & 14 \\
\hline Wakalah atau Wakalah bil Ujrah & 5 & 11 & 12 & 28 & 11 & 4 & 3 & 7 & 4 & 35 & 6 \\
\hline Kafalah atau Kafalah bil Ujrah & 4 & 12 & 7 & 23 & 7 & 2 & 2 & 4 & 2 & 27 & 3 \\
\hline Ju'alah & 6 & 8 & 14 & 28 & 12 & 6 & 5 & 11 & 5 & 39 & 9 \\
\hline Qardh & 7 & 14 & 13 & 34 & 13 & 1 & 1 & 2 & 1 & 36 & 7 \\
\hline
\end{tabular}

Source: Data Processing Results

From table 1 above, it can be concluded that the level ranking from the highest level to the lowest level is taken from the smallest value to the largest value as a determinant of Islamic financial contracts that have the potential for fraud according to the results of data processing carried out, are as follows:

1. According to the conclusion of the ranking value of the number of interviews with experts, the top five ranks of sharia financial contracts are the first is the murabahah contract, the second the ijarah contract, the three ijarah gagiyah bittamlik contracts, the four musyarakah contracts and the five istishna contracts. Furthermore, the sixth to fourteenth ranks are the mudharabah agreement, kafalah or kafalah bil ujrah, salam, musyarakah mutantqisah, mudharabah musytarakah, wakalah or wakalah bil ujrah, ju'alah, qardh, hawalah.

2. According to the conclusion of the total ranking value of the combined data from practitioners and experts, the top five ranks of sharia financial contracts are the first qardh contract, second the kafalah contract or kafalah bil ujrah, the third ijarah contract, the four wakalah or wakalah bil ujrah contracts, the five contracts also. Furthermore, the sixth to fourteenth ranks are the mudharabah, musyarakah, istishna, musyarakah mutanaqisah, hawalah, murabahah, salam, mudharabah musytarakah, ijarah gagiyah bittamlik contracts.

From the two rankings above, conclusions can be drawn based on the sum of the total ranking values that have the lowest value to the highest value as a determinant of the top five ranking conclusions of Islamic financial contracts that have the potential for fraud from the results of data processing carried out are the following contracts.

\section{Conclusion}

Based on the results of the analysis of the research discussion, conclusions can be made: Ijarah contracts in sharia financial contracts have the fifth highest potential for fraud at 0.233400514 or $23.34 \%$ followed by the second rank murabahah contracts at 0.148553299 or $14.86 \%$, the third rank is kafalah or kafalah bil ujrah contracts at 0,087078642 or $8.71 \%$, the fourth rank of the musyarakah contract is 0.082154794 or $8.22 \%$ and the fifth rank of the mudharabah contract is 0.062832599 or $6.28 \%$ and the sixth to the fourteenth rank is the wakalah contract or wkalah bil ujrah, qardh ,, ishtisna, ju'alah, ijarah mintahiyah bittamlik, musyarakah mutanaqisah, salam, mudharabah musytarakah, hawalah and with a rater agreement of 0.995 or $99.5 \%$. 


\section{References}

Abdoerrauf. (1970). Al Quran dan Ilmu Hukum:Comparative Study.Jakarta, Bulan Bintang. Abu Zahrah, Muhammad, Usul al-Fiqh, Ttp., Dar al-Fikr al-“Arabi, tt.

Al-Bukhari, Shahih al-Bukhari. Ttp., Dar al-Fikr, 1994, III : 47, hadis no. 2204.

Al-Hakim, al-Mustadrak. Riyad, Maktabah wa Matabi' an-Nasyr al-Haditsyah, tt.

Al-Kasani, Bada'i ash-shana'i fi Tartib asy-Syaraki', Mesir, Matba'ah al-Jamaliah, 1990

Anwar Samsul, Hukum Perjanjian Syariah, Studi Tentang Teori Akad dalam Fikih Muamalah. Jakarta, PT. Raja Grafindo Persada, 2010.

Ascarya dalam Aam Slamet Rusydiana \& Abrista Devi, Analytic Network Process: Pengantar

Teori dan Aplikasi, Bogor, SMART Publishing, 2013.

Azhar Basyir, Ahmad. (2004). Asas-Asas Hukum Muamalat. Yogyakarta, UII Press.

Azila Ahmad Sarkawi, Akad-Akad Muamalah Dalam Fiqh, Satu Analisis, Jurnal Syariah 6

Az-Zuhaili, Wahbah. (1989). Alfiqh al-Islami wa Adillatuh, jus IV. Damsyik, Dar al-Fikr.

Bala Shanmugam and Zaha Rina Zahari. (2009). A Primer On Islamic Finance, CFA Institute.

Basya, Mursyid al-Hairan ila Ma'rifah Ahwal al-Insan. Kairo, Dar al-Furjani, 1403/1983.

Budi Abdullah and Beni Ahmad Saebani. (2014). Metode Penelitian Ekonomi Islam

(Muamalah), Bandung, Pustaka Setia.

Bunguin Burhan. (2009). Penelitian Kualitatif, Jakarta, Kencana.

Depatemen Agama RI. (2000). “Al-Qur'an dan Terjemahnya”. Semarang, CV. Toha Putra.

Departemen Agama RI, Al-qur'anul Karim watarjamah maaniyah ilal lughoh allndonesiyyah.

Dewi Gemala, Wirdyaningsih, Yeni Salma Barlinti. (2005). Hukum Perikatan Islam di Indonesia. Jakarta, Kencana.

Emzir. (2011). Analisis Data: Metodologi Penelitian Kualitatif, Jakarta, Rajawali Pers.

Geri Hardianto, Harun Delamat, Ahmad Subeki, Analisis Faktor Yang Mempengaruhi Fraud Di

Bank Syariah Yang Terdaftar Di Bank Indonesia. (2016). Akuntabalitas: Jurnal Penelitian dan Pengembangan Akuntansi, Vol. 10, No. 1, Januari.

Haifa Najib, Rini. (2016). Analisis Faktor yang Mempengaruhi Fraud di Bank Syariah, Lampung, Simposium Nasional Akuntansi XIX.

Hendi Suhendi. (2010). Fiqh Muamalah, Jakarta, PT. Raja Grafindo Persada.

Hendri, Abrista Devi. (2013). Metode Penelitia Ekonomi Islam, Jakarta, Gramata Publishing. Ibrahim Warde. (2000). Islamic Finance in the Global Economy, Edinburgh University Press. Ichsan et al, (2021). Determinant of Sharia Bank's Financial Performance during the Covid-19 Pandemic. Budapest International Research and Critics Institute-Journal (BIRCIJournal). P.298-309

Kreuger (1988), dalam Moleong, Metodologi Penelitian Kualitatif, Bandung PT. Remaja Rosdakarya, 2014.

Koentjaraningrat, 1986, dalam Burhan Bungin. (2012). Metodologi Penelitian Kualitatif, Jakarta, Rajawali Pers.

Lexy J. Moleong. (2008). Metodologi Penelitian Kualitatif, Cet. Ke-20, Bandung, Remaja Rosda Karya.

Mardani. (2014). Fikih Ekonomi Syariah, Cet. 2, Jakarta, Kencana.

Miles, Mathew B., dan A. Michael Huberman. (1992). Analisis Data Kualiitatif, Jakarta, Universitas Indonesia-UI Press.

Muhadjir. (2002). Metodologi Penelitian Kualitatif, Yogjakarta, Rakesarasin.

Nawawi, Ismail. (2012).Fikih Muamalah, Bogor, Ghalia Indonesia.

Patton, Michael Quinn. (2006). Metode Evaluasi Kualitatif. Yogyakarta: Pustaka Pelajar.

Permadi, Bambang, AHP Pusat Antar Universitas - Studi Ekonomi, Jakarta, Ul, 1992 
Prayogo, I and Afrizal, T. (2021). Perceptions of Educators, Accounting Students and Accountants Public Accountant against Ethics of Financial Statement Preparation (Studies at University and KAP in Semarang). Budapest International Research and Critics Institute-Journal (BIRCI-Journal). P. 89-101.

Qomarul Huda. (2011). Fiqh Muamalah, Yogyakarta,Teras.

Rahmani Timorita Yulianti. (2008). Asas-Asas Perjanjian (Akad) Dalam Hukum Kontrak Syari'ah, La_Riba, Jurnal Ekonomi Islam, Vol. II, No. 1, Juli

Reskino dan Muhammad Fakhri Anshori, (2016), Model Pendeteksian Kecurangan Laporan

Keuangan Dengan Analisis Fraud Triangle. (2016). Jurnal Akuntansi Multiparadigma, Vol. 7, No. 2, h. 256-269, Agustus.

Rully Indrawan, Poppy Yuniawati. (2014). Metode Penelitian, Bandung, Penerbit Anditama.

Samsul Anwar. (2010). Hukum Perjanjian Syariah, Studi Tentang Teori Akad dalam Fikih Muamalah, Jakarta, PT. Raja Grafindo Persada.

Saaty dan Vargas. (2006). dalam Hendri. (2013). Metode Penelitian Ekonomi Islam, Jakarta, Gramata Publishing.

Steward \& Samdasani (1990), dalam Moleong. (2014). Metodologi Penelitian Kualitatif, Bandung PT. Remaja Rosdakarya.

Strauss, Anselm and Juliet Corbin. (2003). Dasar-dasar Penelitian Kualitatif, Yogjakarta, Pustaka Pelajar.

Sudarsono Heri. (2004). Bank dan Lembaga Keuangan Syariah Deskripsi dan Ilustrasi, Yogyakarta, Ekonisia Kampus Fakultas Ekonomi UII, Ed. 2.

Syafe'I, Rachmat. (2001). Fiqih Muamalah. Bandung, Pustaka Setia.

Wahbah az-Zuhaili. (1989). Alfiqh al-Islami wa Adillatuh, jus IV, Damsyik: Dar al-Fikr.

Zamir Iqbal and Abbas Mirakhor. (2008). Pengantar Keuangan Islam: Teori dan Praktik, Jakarta, Kencana. 